\title{
Switching Party and Anti-Defection Law: Implementation and Impact on Democracy in Indonesia
}

\author{
${ }^{1}$ Akbar Faizal, ${ }^{2}$ Husain Syam \\ ${ }^{1}$ Doctoral Postgraduate Student, Universitas Negeri Makassar, Makassar, South Sulawesi, Indonesia \\ ${ }^{2}$ Professor, Universitas Negeri Makassar, Makassar, South Sulawesi, Indonesia \\ Email: akbarfaizal68@gmail.com,husain6677@yahoo.co.id
}

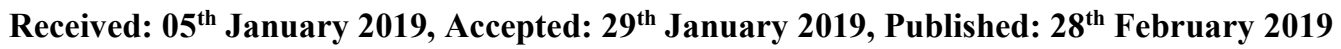

\begin{abstract}
This analysis purposes to provide an overview of the legal framework regarding the transfer of membership of political parties in Indonesia and its impact on the realm of democracy. This study uses qualitative-normative research methods by examining library materials or secondary data, as well as primary and secondary legal materials. The study uses the four approaches namely statute approach, conceptual approach, comparative approach, and historical approach. The results of this study indicate that the ban was carried out by giving recall rights to political parties to revoke their membership in parliament and replace it with other members. The high impact is to maintain the stability of government both the legislature and the executive while the adverse effect is the hostility of strong democracy when there is a difference between the will of the constituents and the interests of the party.
\end{abstract}

Keywords

Legislative Party Switching, Parliamentary Expulsion, Political Party, Political Representation

\section{Introduction}

Political parties are important organizations in a democratic country [1]. Its role is very strategic because it can affect the filling of public positions that will determine the direction of state policy [2]. Charging public posts directly related to political parties is the position of the legislator. Especially in Indonesia, one cannot develop a member of the Parliament without going through political parties.

In countries with advanced democracies, members of political parties not bound by strict rules [3]. Every party member who holds a legislative position given the freedom to defend the voice of his voting community compared to the orders of political parties [4]. As in America, members of parliament who move political parties during their term of office cannot be stripped of their political membership status by political parties [5]. However, in some other countries, the transfer of membership of political parties during their term of office gives the party the right to remove their political membership status. Such conditions place parliamentarians in a dilemmatic position. They must remain standing in favor of policies by party orders if they do not want to lose office although this is against the will of the voters, even their conscience [6].

Compliance with members of the Parliament towards bearer parties is an absolute matter. Because members who do not obey the orders of the party can be removed from their positions in the Parliament and replaced with other cadres (Substitution Between Time) [7]. Likewise, members of the Parliament who moved political parties while in office (switching party) because they felt the will of their constituents were no longer in line with the party [8]. Such rules are considered to be very restraining members of the Parliament to act independently and objectively.

Research conducted in 2007 by the Council of Europe and Hans Breeveld showed that from 193 countries in the world, only 41 imposed a ban on the transfer of political parties by legislators [9]. The majority of states that enforce this rule are those who are new to democracy where the scent of authoritarianism still felt. So, what is created is only formal democracy. J.J. Rousseau said that formal democracy (mere formality) is similar to slavery when there are just a few egalitarian ones that have political legitimacy [10]. Democracy no longer puts the people as the highest decision makers, but shifts to a handful of party elites.

The vitality of the position of political parties in Indonesia is not directly proportional to the level of public trust. The survey released by the Indobarometer Institute in 2017 showed that around $51.3 \%$ of the people considered political parties wrong [11]. Parallel to that, the Parliament as a representation of the power of political parties in government is also considered to be the most corrupt institution [12]. People's distrust of political parties and representative bodies suspected due to political party restraints on the decisions of their cadres who sit in parliament [13]. Parliamentarians must always obey party orders rather than the decisions of their conscience, even the interests of constituents [14]. As a result, many rules not desired by the people but still legalized.

The facts above prove that there are strong interventions from political parties to their members in parliament legally and nonlegally, so often the public policies produced are not purely on the interests of constituents, but tend to be the will of the party. For this reason, it is essential to study how this impact on representative democracy in Indonesia. 


\section{Literature Review}

Constitutions in democratic countries come from constituent power [15]. At a lower level, the will of the people represented by crystallized political parties became public policy in the form of laws. Political parties are vital organizations in democratic countries, even said there is no democracy without political parties because political parties are the primary container in the implementation of representative democracy [16].

Representative politics is a concept of aggregation and expression of people's choices which are considered collective actions [17]. This choice is determined by a legitimate representative who is usually called the political elite [18]. Political elite theory divides humans into two types [19]:

1) A handful of people who are capable and therefore occupy positions to govern;

2) A large number of masses destined to be regulated.

Historically, various theoretical literature on representative politics has a focus on whether a representative must act as a delegate or trustee. Representatives who are firmly bound and always follow the choices expressed by the constituents are referred to as delegates while the trustee makes decisions based on intuition and self-understanding of a situation [20].

\section{Research Methods}

This study uses qualitative-normative research methods by examining library materials or secondary data, as well as primary and secondary legal materials. As stated by Morris L. Cohen, this study uses four approaches namely statute approach, conceptual approach, comparative approach, and historical approach [9].

1) The statute approach is used to dissect relevant laws and regulations to obtain positive legal facts (ius constitutum) regarding the rules for moving political parties to members of the Parliament.

2) The conceptual approach used by raising the basic concepts of representative democracy and political parties as general references to describe the philosophical foundation of the ideal condition of freedom in Indonesia.

3) The comparative approach is used by comparing the conditions prevailing in world countries with what happens in Indonesia through international reports issued by individual institutions.

4) The historical method used by tracing the history of the adoption of democratic forms of government in Indonesia. Also, it also tracks the plenary meeting of the Parliament which contains the decision making of public policy (Act) from the minutes of the plenary session of the Parliament from 2012 to 2018.

\section{Result and Discussions}

Indonesia in its constitutional preamble has declared to be part of international relations by participating in carrying out world order based on freedom, eternal peace, and social justice. Indonesia presents itself as part of the global world as a democracy that places the highest sovereignty in the hands of the people (salus populi suprema lex esto), taken with the spirit of the application of the law that must take from the experience of the nation itself [21].

The failure to translate parliamentary-liberal democracy motivated by the language of the failure of western practice in Indonesia due to its incompatibility with the national socio-cultural conditions [22]. The practice of democracy has changed into a guided democracy. Soekarno conceived this concept by assuming this was a harmonious solution with the soul of the Indonesian people [23]. In 1955, Soekarno made a declaration to abolish the concept of liberal democracy which put a decision on a majority vote, replaced by a cooperative spirit in which decisions made through a joint decision [24]. Soekarno said that Indonesia needed a democracy led by a leader to unite all elements of the Indonesian people. However, in practice, the unification was carried out by accommodating government support parties and burying other parties that were not in line, such as Masyumi and PSI which were dissolved by Soekarno [25]. Guided democracy that concentrates all decisions and thoughts centered on the head of state turns out to create an authoritarian government [26]. This authoritarianism also raises variously armed rebellions which impact on the country's financial instability which causes poverty to run rampant. In the end, the guided democracy regime that Soekarno carried out fell along with his power and replaced with the New Order era with President Soeharto [27].

\section{- Members of Parliament: Personal Interest, Constituents, or Party}

Political parties as residents of Parliament considered as the only institution that can translate the interests and values of society into binding legislation and public policies. As a foundation for democracy, they gather public interest, articulate it in the form of policy choices and provide a structure for participating in politics[28].

Although the role of political parties is very strategic as a representation of society, in the development of parliamentary institutions, their meetings are almost always closed. Likewise, regarding internal party rules, although sometimes it is open to the public, what written does not always reflect actual practice. Especially when there is a dominant group or existing habits to regulate the performance of parliamentary groups, such conditions naturally present a firm line as enforcing the discipline of cadres towards the party.

In Indonesia, juridical enforcement of anti-defection law has been in place since the issuance of Law Number 31 of 2002 concerning Political Parties, this is the first basis for the anti-defection ban in which Article 12 of the Law expressly states 
that members of political parties become members the people's representative institution can terminate from the people's representative institution if: a) declares to resign from a political party membership or claims to be a member of another political party; b) dismissed from the membership of the relevant political party for violating the articles of association and by-laws; or c) violate the laws and regulations that cause the person to be dismissed. Previously, in Law number 2 of 1999 concerning Political Parties, the regulation did not exist.

In many countries, defections are believed to be a movement to use against political opportunism and bribery to move. To overcome this formal law was made to enforce party discipline. Anti-defection is a necessity so that parliamentarians can carry out the will of their people by maintaining the proportionality of power in parliament. Strong political parties can easily tempt MPs to move parties by selling their seats. It increases the number of corruptions in parliament and disrupts the stability of the government [29]. If parliamentarians easily move to larger political parties with impressive offers, free competition will be static. The condition of democracy with minimal competition will degrade government performance [30].

The instability of the polarization of the power of political parties in parliament will threaten the course of government [31]. With a large number of members, defection of a member of parliament against the party without leaving their seats can change the balance of power in the parliament without even involving democratic elections, also though the determination of the composition of forces in parliament must always involve the people [32].

Congressional study has long recognized that personal incentives motivate the voices of legislative representatives. Deputies usually get value from supporting their party, but sometimes incentives are weak [9]. Presumably, the relationship between personal progress and party loyalty is most influential in the established and stable parliamentary party system and the weakest in the new and unbalanced party structure. But even so, as Montgomery found, representatives in a transitional system (Hungary in 1994) soon learned "that parties are the key to fulfilling their personal goals" [33]. However, observers of a smooth party system (Ukraine since 1994), found that "poor policy outcomes" could "create election incentives for legislators to divert parties before elections" [34].

\section{- Preventing Defection by Party Members Without Positive Law}

The emphasis of the discussion in this article is to normatively describe the legal basis for the entry into force of anti-defection law in Indonesia. The above study has explained that the anti-defection law has been in effect since 2002 in the Law on political parties, and continues to institutionalize in the amendment of the Act in 2011, and strengthened in the Law governing the representative body of the people of the Republic of Indonesia.

The application of anti-defection law in Indonesia does not bring the Indonesian legislature's condition in a better direction. Looking at the World Justice Project data [35], Indonesia's ranking in the absence factor in terms of corruption, precisely in the legislative branch indicator does not use its position for personal gain, Indonesia is ranked 84 with a score of 0.38 , far from Malaysia which is rated 39 with a score of 0.61 , and very far from Denmark ranked 1 with a score of 0.96. However, this assessment seems less concrete, because Singapore has an index with a score of 0.93 and is ranked 2, even though Singapore is also a country that applies anti-defection law.

Based on sources from $[36,37]$ which can see in Table 1, which identifies 41 countries with party anti-defection laws then classifies them according to the type of democracy that is classified by [38] sourced from [39].

\begin{tabular}{|c|c|c|c|}
\hline $\begin{array}{l}\text { Type of } \\
\text { Democracy }\end{array}$ & of nations & $\begin{array}{l}\text { Those with floor } \\
\text { crossing laws }\end{array}$ & Nations with Floor-Crossing Laws \\
\hline $\begin{array}{l}\text { Older } \\
\text { democracies }\end{array}$ & 36 & $5(14 \%)$ & Portugal, India, Israel, Trinidad \& Tobago \\
\hline $\begin{array}{l}\text { Newer } \\
\text { democracies }\end{array}$ & 54 & $13(24 \%)$ & $\begin{array}{l}\text { Belize, Bulgaria, Ghana, Guyana, Hungary, Lesotho, Mexico, } \\
\text { Namibia, Romania, Samoa, Senegal, Suriname, Ukraine }\end{array}$ \\
\hline Semi-democracies & 58 & $19(33 \%)$ & $\begin{array}{l}\text { Armenia, Bangladesh, Fiji, Gabon, Kenya, Macedonia, Malawi, } \\
\text { Mozambique, Nepal, Niger, Nigeria, Papua New Guinea, } \\
\text { Seychelles, Sierra Leone, Tanzania, Singapore, Zambia, Sri } \\
\text { Lanka, Uganda. }\end{array}$ \\
\hline Non-democratic & 45 & $4(9 \%)$ & Thailand, Congo (Democratic Republic), Zimbabwe, Pakistan. \\
\hline Total & 193 & 41 & \\
\hline
\end{tabular}

Tabel 1. Countries with the Anti-Defection Law of the Party 
Data from Table 1 were obtained accurately in 2007. In the table, it can see that only around $14 \%$ of developed democracies require that their parliamentarians withdraw if there is a transfer of political parties. New Zealand and South Africa are two countries ignoring such laws. Instead, there are $33 \%$ of countries classified as semi-democratic countries, and only $9 \%$ of nondemocratic countries are anti-defection political parties. Laws that prohibit party defection occur in democracies that are only compared to established democracies [9].

Defections carried out by parliamentarians threaten the stability of forces in parliament which has an impact on the effectiveness of government [40]. However, the restraint of parliamentarians in expressing opinions by the party can also hinder the pace of representative democracy. For this reason, prevention of defection is better done through non-legal means by prioritizing political ethics. In this case, ideology can be used as a tool to tie members to their party ethically [41].

The Indonesian Constitution provides freedom of association, assembly, and opinion. This right does not apply to anyone including members of parliament. However, especially for parliamentarians, the right to express their opinions is limited by the party's will. Although restrictions on human rights indeed recognized in the Republic of Indonesia's constitution, the granting of rights with an article in the constitution by being given restrictions with other articles is tantamount to giving rights through one hand, then taking it back with the other hand [42].

By way of strengthening party ideology towards members, defection can prevent. Ideology affects the probability of defection because of 2 (two) things. First, ideology has a high correlation with cohesion. Because the bond of loyalty can be built with the similarity of ideology that is adopted and carried out by political parties consistently [31]. The problem often faced in Indonesia is that political parties often emerge from the ideology of their party. Especially the person who holds the position of administrator.

In accordance with the research carried out by Karvonen [43], regarding the law of political parties based on the law imposed by 39 countries. From the research shows that the level of democracy in a country related to restrictions by political parties is distinctly different. Forward and previous democracy of a country can be seen from the party law that is applied. Even though the research did not specifically address anti-defection laws, but could translate as the restrictions carried out by political parties were rarely carried out in developed democracies.

\section{Conclusions}

The anti-defection law caused a lack of votes from members of political parties opposite their faction, resulting in a decrease in the level of free competition in the Parliament space which could result in a decline in the performance of the government itself. Although the application of anti-defection law deemed incompatible with the characteristics of modern and advanced democracies if there is a significant and fluid defection of MPs it can cause instability of the government. Therefore, defection is also not something that must be done but must avoid. However, avoidance must not be done by entering a ban in the Law which causes members of parliament to lose their seats if they defect from the party. Prevention of defection must be done by strengthening political ethics so that party members are bound ethically to the ideology of the party they have chosen. To do that, political parties through their leaders and administrators must commit to embracing party ideology in every practical political choice.

\section{References}

1. Van Biezen I. Political parties in new democracies: Party organization in Southern and East-Central Europe. Springer; 2003.

2. Hicken A, Kuhonta EM. Party system institutionalization in Asia: democracies, autocracies, and the shadows of the past. Cambridge University Press; 2014.

3. Dalton RJ. Political parties and political representation: Party supporters and party elites in nine nations. Comp Polit Stud. 1985;18(3):267-99.

4. Reynolds A. The architecture of democracy: constitutional design, conflict management, and democracy. OUP Oxford; 2002.

5. Ware A. Political parties and party systems. Vol. 9. Oxford University Press Oxford; 1996.

6. Case W. Politics in Southeast Asia: democracy or less. Routledge; 2013.

7. Esaiasson P, Holmberg S. Representation from above: Members of parliament and representative democracy in Sweden. Routledge; 2017.

8. Mershon C. Legislative party switching. Oxford University Press Oxford; 2014.

9. Janda K. Laws against party switching, defecting, or floor-crossing in national parliaments. World Congress of the International Political Science. Santiago, Chile: The Legal Regulation of Political Parties; 2009. (Party Democracy and Party Law: The Legal Regulation of Political Parties in Modern Democracies).

10. Rousseau J-J, May G. The social contract: And, the first and second discourses. Yale University Press; 2002.

11. Tempo.co. Survei: Partai Politik Makin Tidak Dipercayai Masyarakat [Internet]. tempo.co. 2017 [cited 2018 Aug 17]. Available from: https://nasional.tempo.co/read/858765/survei-partai-politik-makin-tidak-dipercayai-masyarakat

12. Heller W, Mershon C. Political parties and legislative party switching. Springer; 2009. 


\section{Helix Vol. 9 (1): 4818- 4822}

13. Carty RK, Young L, Cross WP. Rebuilding Canadian party politics. UBC Press; 2000.

14. Weaver RK. The politics of blame avoidance. J Public Policy. 1986;6(4):371-98.

15. Thompson B. Textbook on constitutional \& administrative law. Blackstone Press; 1997.

16. Hofmeister W, Grabow K. Political parties: Functions and organisation in democratic societies. Konrad Adenauer Stiftung; 2011.

17. Schweber H. The Language of Liberal Constitutionalism. Cambridge University Press; 2007.

18. Schweber H. The "Science" of Legal Science: The Model of the Natural Sciences in Nineteenth-Century American Legal Education. Law Hist Rev. 1999;17(3):421-66.

19. Varma SP. Modern political theory. Vikas Publishing House PVT LTD; 1975.

20. Dovi S. Political representation. 2006.

21. Holmes OW. The common law. Harvard University Press; 2009.

22. Ramage DE. Politics in Indonesia: Democracy, Islam and the ideology of tolerance. Routledge; 2002.

23. Van der Kroef JM. "Guided Democracy" in Indonesia. Far East Surv. 1957;26(8):113-24.

24. Agensky J, Barker J. Indonesia and the liberal peace: Recovering southern agency in global governance. Globalizations. 2012;9(1):107-24.

25. Mackie JAC. Indonesian politics under guided democracy. Aust Outlook. 1961;15(3):260-79.

26. Bhakti IN. The transition to democracy in Indonesia: some outstanding problems. Asia-Pacific a Reg Transit. 2004;195206.

27. Lev DS. The political role of the army in Indonesia. Pac Aff. 1963;349-64.

28. Sulistyo H. Electoral politics in Indonesia: A hard way to democracy. Croissant/Bruns/John. 2002;75-100.

29. Kelly N, Ashiagbor S. Political parties and democracy in theoretical and practical perspectives. New York NDI, USAID. 2011;

30. Sørensen RJ. Political competition, party polarization, and government performance. Public Choice. 2014;161(34):427-50.

31. Volpi E. Ideology and Party Switching: A Comparison of 12 West European Countries. Parliam Aff. 2018;

32. Nielsen MK, Andersen AM, Pedersen HH. Balancing Costs of Legislative Party Switching in the Danish Parliament 1953-2015. Parliam Aff. 2018;

33. Montgomery KA. Electoral effects on party behavior and development: evidence from the Hungarian National Assembly. Party Polit. 1999;5(4):507-23.

34. Slomczynski KM, Shabad G, Zielinski J. Fluid party systems, electoral rules and accountability of legislators in emerging democracies: The case of Ukraine. Party Polit. 2008;14(1):91-112.

35. World Justice Project. Rule of Law Index Report [Internet]. 2016. [cited 2019 Dec 18]. Available from: https://worldjusticeproject.org/our-work/publications/rule-law-index-reports/wjp-rule-law-index®-2016-report

36. Council of Europe. Amendments to the Constitution of Ukraine adopted on 8 December 2004 (CDL Opinion 339/2004) [Internet]. 2005. Available from: http://www.venice.coe.int/webforms/documents/default.aspx?pdffile=CDL(2005)036e

37. Breeveld H. Democratie, Participatie en Besluitvorming in Politieke Partijen. Lecture provided at the Institute of Graduate Studies and Research. 2009.

38. Norris P. Democracy Indicators Cross-NationalTime-SeriesDataset. Pippa Norris Data Shar Data Sets. 2005;

39. Freedom House. Freedom in the World 2005: civic power and electoral politics. New York Free House. 2005;

40. Tavits M. Effect of local ties on electoral success and parliamentary behaviour: The case of Estonia. Party Polit. 2010;16(2):215-35.

41. Heller WB, Mershon C. Party switching in the Italian Chamber of Deputies, 1996-2001. J Polit. 2005;67(2):536-59.

42. Wheare KC. Modern constitutions. Vol. 213. London; New York: Oxford University Press; 1951.

43. Karvonen L. Legislation on political parties: a global comparison. Party Polit. 2007;13(4):437-55. 